\title{
De nye i Unionen
}

\section{Karsten Fledelius}

\section{Så kom Bulgarien og Rumænien endelig med i EU. Det skyldtes mere god vilje, end at de to lande var parate}

Bulgarien og Rumænien er nabolande i Østeuropa. De har begge været monarkier, har haft kommunistisk styre efter Anden Verdenskrig og er nu republikker med demokratisk styreform, selv om de afsatte konger fra 1940'erne, hhv. Simeon II (194346) og Mihail I (1940-47), i dag igen spiller en vis politisk rolle.

Det er de første lande efter Grækenlands og Cyperns optagelse, hvor flertallet af befolkningen tilhører den ortodokse kirke. Begge lande hører til den fattige del af Europa og har længe ligget nogenlunde på linje hvad angår bruttonationalprodukt pr. indbygger. Begge blev 2004 optaget i NATO og er fra 1. januar 2007 optaget i EU.

Men så hører ligheden også op. De to lande er meget forskellige. Først er der sproget: Bulgarerne taler et sydslavisk sprog, mens flertallet af Rumæniens indbyggere taler et romansk. Bulgarien har et stort tyrkisk, muslimsk mindretal foruden et mindre bulgarsk-talende mus- limsk mindretal (knap 10 pct. tyrkere, knap fire pct. pomakker). Rumænien har et stort ungarsk, katolsk eller reformert mindretal, men intet muslimsk mindretal af betydning. Bulgariens ortodokse kirke er splittet $\mathrm{i}$ to hinanden bekæmpende synoder og har trukket sig ud af internationalt kirkeligt arbejde. Rumæniens ortodokse kirke er en af de mest progressive ortodokse kirker i Europa og en vigtig deltager i intereuropæisk kirkeligt samarbejde.

Fælles for begge landene er en tung arv fra den tid, hvor de blev regeret af hver sit kommunistiske dynasti. Deres diktatorer, som nærmest havde kongelig status (Rumæniens Ceaucescu havde oven i købet flere sceptre!), havde begge i 1980'erne ført en hårdhændet nationalistisk politik og forfulgt landenes største minoriteter, hhv. tyrkerne og ungarerne.

Men hvor Todor Zjivkov i Bulgarien blev afsat på fredelig vis og fulgt til graven af store menneskemæng- 
der, da han endelig døde i år 2000, var opgøret med den rumænske diktator Nikolae Ceaucescu en opvisning i kommunistisk justitsmord. Ikke fordi Ceaucescu ikke havde været en benhård hersker med mange forbryderiske handlinger på samvittigheden. Men fordi han blev styrtet ved et paladskup af sine egne folk, som derefter sad til doms over ham og hans kone ved en primitiv, dobbeltmoralsk skueproces optaget på video og vist i stærkt manipuleret form.

\section{Lang vej igen}

I ingen af landene er der blevet ryddet ordentlig op i det overdimensionerede sikkerhedsapparat. I begge landene er den politiske elite i vid udstrækning rekrutteret blandt folk, for hvem første del af deres karriere var afhængig af, at de lydigt indordnede sig under det kommunistiske system. Og begge lande har i længere perioder direkte været regeret af demokratisk valgte politikere med en fortid i de gamle diktatorers magtapparat.

I begge lande er lovgivningen i udgangspunktet dybt præget af tiden under kommunismen. Blot at reformere retsvæsnet, endsige privatisere de store statsvirksomheder, er et gigantisk job. Korruption har siden demokratiseringen været et udbredt fænomen i begge lande og ikke begrænset til ekskommunisterne - også politikere med ikke-kom- munistisk baggrund har forstået at rage til sig. Derfor har det været en kamp ikke blot at tilpasse lovgivningen til de europæiske standarder for god regering, menneskerettigheder og reel markedsøkonomi, men i endnu højere grad at få den implementeret. Det er faktisk imponerende, hvor langt de to landet trods alt er nået. Men der er lang vej igen.

Ligesom i tilfældet med lande som Letland og Litauen har man fra europæisk hold lukket øjnene for mangt og meget for at få processen til at lykkes. Men med de små baltiske lande har alene størrelsen gjort integrationsprocessen lettere.

Bulgarien er et land, der dækker over dobbelt så stort et areal som Danmark, med ca. 7,5 millioner indbyggere - Rumænien er mere end fem gange så stort med ca. 21,5 millioner. Det er derfor en stor mundfuld, EU igen skal fordøje, selv om udvidelsen $\mathrm{i}$ år trods alt er væsentlig mindre end den i 2004. Og her kommer igen korruptionsproblemet ind som et af de allervæsentligste. For nu skal de to lande modtage støtte fra EU's fonde. Og hvordan sikrer vi os, at pengene kommer derhen, hvor de skal, og ikke svindles væk undervejs?

Tvivlen på de to landes ydeevne $\mathrm{i}$ kontrol med tilskuddene var en af grundene til, at der i tiltrædelsestraktaterne var indført en bestemmelse om, at optagelsen i EU kunne udskydes med et år, hvis optagelseskriterierne ikke vurderedes som til- 
strækkeligt opfyldt. Endnu i foråret 2006 var der ikke givet grønt lys fra EU. Først i efteråret kom godkendelsen. Men da var der også foregået ret dramatiske ting ikke mindst i Rumænien.

\section{Korruption i Rumænien}

Rumænien var i 2003 blevet udsat for en særdeles barsk rapport fra Europa-kommissionen, som ud over helt utilstrækkelig korruptionsbekæmpelse bl.a. kritiserede dårlig behandling af landets forskellige mindretal. Det blev der taget skridt til at gøre noget ved, således vedtoges ved en folkeafstemning i september 2003 en forfatningsændring, som væsentligt udvidede mindretallenes rettigheder. Hvad korruptionen angår, fyrede ministerpræsident Adrian Nastase samme måned tre ministre, hvoraf ministeren for europæisk integration havde gjort sig skyldig i at lede EU-støttemidler videre til sin mands og sin søns firmaer.

I 2004 blev Rumænien, med dets ekskommunistiske præsident Ion Iliescu og dets ekskommunistiske ministerpræsent Nastase, medlem af NATO, klart bakket op af et flertal af parlamentet og befolkningen.

Ved præsident- og parlamentsvalgene i december 2004, hvor Nastase med en snæver margen blev slået af Traian Basescu, og hvor hans parti mistede regeringsmagten, var lederne på begge fløje helt enige om at arbejde videre frem mod en optagelse i EU. Men endnu i efteråret 2005 havde Rumænien ikke opfyldt 14 af de ca. 30 kriterier for optagelse. I foråret 2006 var man kommet ned på at mangle fire områder, tre inden for landbrugs- og veterinærsektoren og ét vedr. finans- og skatteadministrationen, mens kriterierne for korruptionsbekæmpelse ansås for at være tilstrækkelig opfyldt.

Europa-Kommissionsformand Barroso fandt det ikke desto mindre nødvendigt med en grundlæggende reform af retsvæsnet. En sådan var blevet vedtaget i 2005 af parlamentet trods intens modstand fra den socialistisk-nationalistiske oppositions side, men forfatningsdomstolen havde siden erklæret dele af reformen for forfatningsstridig.

Det førte til, at ministerpræsident Calin Popescu-Tariceanu fra det Nationalliberale parti (en del af den Demokratiske Alliance for Retfærdighed og Sandhed som vandt valget i december 2004) den 7 . juli 2006 indgav sin afskedsbegæring for at gennemtvinge et parlamentsvalg om efteråret. Det ville præsident Traian Basescu dog ikke acceptere, han greb ind den 12. juli og pressede partierne til at genoptage forhandlingerne om en justitsreform med en modificering af de dele, som forfatningsdomstolen havde modsat sig. Præsidentens dristige indgriben, som klart havde forholdet til EU som baggrund, lykkedes 
faktisk, og den 19. juli trak ministerpræsidenten sin afskedsansøgning tilbage, dog med den nødretstilstand, der var opstået som følge af store oversvømmelser, som begrundelse!

Helt grebet ud af luften var Popes$\mathrm{cu}$-Tariceanus begrundelse dog ikke. Faktisk var situationen meget alvorlig, mindst 20 mennesker omkom i juli efter de heftige regnskyl, og tusinder af mennesker måtte evakueres, og i august skete noget lignende med 28 dødsofre - de samlede skader er blevet opgjort til over 1,5 milliarder euro. Efter ministerpræsidentens mening var omfanget af naturkatastrofen i høj grad en følge af manglende implementering af lovgivningen og manglende vedligeholdelse, ja selv sløjfning af diger. Om baggrunden er slendrian eller direkte korruption er et andet spørgsmål.

Korruptionsspørgsmålet er i det hele taget noget, den nye rumænske regering har gjort noget alvorligt ved. Det startede i 2005 med vedtagelse af en 'national strategi for kampen mod bedrageri og varetagelse af EU's finansinteresser i Rumænien' og en omstrukturering af den Nationale Antikorruptionsdirektion, DNA, som blev placeret direkte under rigsadvokaturen og kraftigt oprustet hvad angår personale og ressourcer, herunder med eksperter inden for bank- og toldvæsen samt IT. Dette skete under heftig modstand fra oppositionen i parlamentet. Det var klart, at man nu ville gå efter toppen af systemet.
En af de første anklagede blev da også tidligere ministerpræsident og præsidentkandidat for PSD Adrian Nastase, som nu var formand for parlamentet. Nastase måtte træde tilbage fra denne post og betegnede selvfølgelig anklagen som rent politisk. Også generalsekretæren for PSD og to forhenværende PSD-ministre, finansministeren og transportministeren blev anklaget.

Men DNA's le blev også svinget på regeringspartiernes mark. Viceministerpræsident George Copos, en af Rumæniens rigeste mænd og medlem af ledelsen af det Konservative Parti, måtte trække sig tilbage efter anklager for skattesnyd og embedsmisbrug, og den nationalliberale toppolitiker Dinu Patriciu, leder af landets næststørste oliekoncern, Rompetrol, blev anklaget for korruption, hvidvaskning af penge, skatteunddragelser og bedrageri.

Det begyndte at gøre så ondt også i regeringspartierne, at politikere fra begge sider af parlamentet fik senatet til i februar at fælde et vedtaget lovforslag om en yderligere udvidelse af DNA's beføjelser. Men deputeretkammeret vedtog lovforslaget igen, efter at regeringen havde fået styr på sit eget bagland.

Man kan på denne baggrund godt forstå, hvorfor Europa-Kommissionen ikke i foråret 2006 blot ville annoncere, at Rumænien måtte vente et år til, men den 16. maj udsatte beslutningen til om efteråret. Kombinationen af gulerod og stok havde 
virket på et af de allermest vanskelige punkter: der blev endelig gjort en helhjertet indsats mod en korruption, som tilsyneladende var bundløs, og som omfattede politikere fra stort set alle partier. Derfor var det ikke nok for den nye generation af politikere at vinde præsidentog parlamentsvalget i 2004, det gjaldt også om at vinde kampen om europæiske standarder for redelighed i den offentlige forvaltning i deres egen politiske bagland.

\section{Bulgariens regeringskrise}

På mange måder har problemerne været de samme før Bulgariens endelige optagelse i EU. Landet startede allerede 1997 på en moderniseringsproces, hvor man fik standset en inflation, som havde været op til 50 pct. pro anno, og indført en fastkurspolitik, som bandt valutaen til D-mark og fremmede udenlandske investeringer, men havde betydelige sociale omkostninger. Samtidig ramtes landet hårdt af blokaden af Serbien i disse år og hærgedes af korruption og fattigdom.

I år 2000 oplevede jeg selv, hvordan vejskilte på motorvejene var blevet fjernet for at blive brugt som tagbeklædning på hytter. Det var noget af baggrunden for den opsigtsvækkende valgsejr, Nationalbevægelsen for Simeon II fik i 2001. Eks-tsaren var blevet populær, fordi han havde gjort en udmærket karriere i erhvervslivet og nu interesserede sig for at gøre noget for sit fødeland. Mange i befolkningen håbede, at hans personlige succes ville smitte af på Bulgarien.

Hvilken stilling denne ejendommelige personlighed skulle indtage $\mathrm{i}$ Republikken Bulgarien, var ikke fra starten klart. Men det endte med, at han lod sig udnævne til ministerpræsident under det til lejligheden skabte særprægede borgerlige navn Simeon Sakskoburggotski (grundlæggeren af kongehuset, hans bedstefar tsar Ferdinand I, var af den tyske fyrsteslægt Sachsen-Koburg-Gotha).

Som det kunne forventes, kunne han ikke indfri de klart overdrevne forventninger, der blev stillet til ham, trods gode intentioner og pæn nationaløkonomisk fremgang. Det gik fremad med tilpasningen til EU, men langsomt. Det lykkedes at få Bulgarien optaget i NATO i 2004 på linje med Rumænien. Men det var sværere med EU-processen. Og det lykkedes ikke for regeringen at nå sine mål om afskaffelse af korruption, effektiv bekæmpelse af kriminalitet og en generel forbedring af befolkningens levevilkår, ligesom arbejdsløsheden stadig var for høj (officielt over 10 pct., sammenlignet med Rumæniens knap seks pct.), og mange unge udvandrede fra landet.

Imidlertid førte parlamentsvalget i juni 2005 ikke til den ellers fra Central- og Østeuropa velkendte situation, hvor der sker et 'systemskifte' ved hvert valg. Nationalbevægelsen for Simeon, NDS, gik godt nok tilba- 
ge fra 120 (af 240) til 53 mandater, mens Koalitionen for Bulgarien med socialisternes parti BSP som det vigtigste gik frem fra 48 til 82 mandater, og Bevægelsen for Rettigheder og Friheder (DPS) gik frem fra 21 til 34 mandater. De Forenede Demokratiske Kræfter, som havde haft ledelsen af regeringen 19972001, led endnu et valgnederlag og gik tilbage fra 51 til 20 mandater. Til gengæld vandt tre nye partier hele 51 mandater. Kort sagt et rigtig mudret valgresultat.

Simeon Sakskoburgski ønskede i denne situation at danne ny regering, mens socialisterne krævede ministerpræsidentposten for BSP-formanden Sergej Stanisjev og yderligere ville gennationalisere de kongelige ejendomme, som var givet tilbage til Simeon og hans familie. Det endte efter knap to måneders regeringskrise med, at Stanisjev blev ministerpræsident, men frafaldt kravet om gennationalisering af de kongelige ejendomme, og at der dannedes en stor koalition med otte ministre fra socialisterne, fem ministre fra Simeons Bevægelse og tre ministre fra DPS, og at de sidste fik de særlig EU-vigtige miljø- og landbrugsministerier, mens BPS sikrede sig statsog udenrigsministerposterne. Der er ingen tvivl om, at det var udsigten til at sakke bagud i optagelsesprocessen, som bevirkede denne opsigtsvækkende vilje til at finde en løsning på en regeringskrise, som klart ikke var, hvad landet havde brug for.
Hvad landet havde brug for, var handlekraft. For EU var stadig ikke tilfreds. Der var hele seks områder, som gav Europa-Kommissionen 'anledning til alvorlig bekymring'. Det drejede sig først og fremmest om vanskelighederne ved at kontrollere, om EU-støttemidlerne gik i de rette lommer, sammenhængen mellem organiseret kriminalitet og politisk og administrativ korruption, og hvidvaskning af penge og andre former for bedragerisk virksomhed.

Dertil kom i februar 2006 en yderst barsk rapport fra to tyskere udsendt af Europa-Kommissionen, som havde undersøgt politi og justitsvæsen og påpeget korruptionens indtrængen i sikkerhedsorganerne, med forbindelser mellem korruptionen i politi og retsvæesen og organiseret kriminalitet. Rapporten påpegede blandt andet, at der i 2005 var blevet begået mere end 150 bestilte mord, og at ingen af dem var blevet opklaret.

Der blev dog ikke så meget konflikt omkring en justitsreform i Bulgarien som i Rumænien. Parlamentet vedtog flere love herom i oktober-december 2005, og i januar 2006 udnævntes en ny rigsadvokat. Alligevel fik heller ikke Bulgarien grønt lys af Europa-Kommissionen den 16. maj 2006.

\section{Var det for tidligt?}

I Bulgarien som i Rumænien var glæden stor, da Europa-Kommissio- 
nen i efteråret alligevel accepterede at følge den oprindeligt fastsatte tidsplan og lade begge lande blive medlemmer pr. 1. januar 2007.

Er Bulgarien og Rumænien kommet for tidligt med i EU? Det kunne man argumentere med ud fra flere kriterier. Et af dem er, at begge de to lande i henseende til bruttonationalindkomst pr. indbygger ligger noget under de økonomisk svageste af de lande, som blev optaget i 2004, Letland og Litauen. De ligger bagud for et ansøgerland som Tyrkiet og langt bagud i forhold til Kroatien, hvis bruttonationalindkomst pr. indbygger er over dobbelt så høj.

På den anden side er det mærkbart, hvor hurtigt økonomien ofte forbedres i nye EU-lande efter optagelsen, og der er ingen grund til at tro, at det samme ikke skulle være tilfældet med disse to lande, hvoraf $\mathrm{Ru}$ mænien for øjeblikket nok har lidt bedre levevilkår for befolkningen generelt (blandt andet på grund af lavere arbejdsløshed) end Bulgarien.

Der er imidlertid næppe tvivl om, at der aldrig var blevet gennemført så drastiske forbedringer i stat, finanser og lovgivning, som det har været tilfældet $\mathrm{i}$ begge lande gennem de seneste år, hvis de ikke havde haft EU-målet tæet på. EU's rolle som 'forbedringskatalysator' har haft en vældig betydning. Det gælder også på områder som behandling af minoriteter, som især har været et problem i Rumænien, da landet blev regeret af en socialistisk re- gering med ultranationalistisk støtte. Professor Ole Wæver har engang sagt, at NATOs største succes lå efter $1990 \mathrm{i}$ at forhindre en krig mellem Rumænien og Ungarn om Transsylvanien ved at sætte god opførsel som en betingelse for partnerskab. Præcis det samme er i endnu større grad tilfældet med EU's indsats på det østlige Balkan, som nu er blevet en del af unionen.

Til spørgsmålet om, hvorvidt det var for tidligt, skal man måske snarere sige, at det var 'rettidig omhu' at stile efter en så tidlig optagelse af Bulgarien og Rumænien. De er efter eget ønske blevet optaget i et fællesskab styret af normer, som de har hårdt brug for til at komme ud af økonomisk og politisk nød. Og de nuværende regeringer har ydet en betydelig indsats for at komme på omgangshøjde med kravene. Skal man vurdere ud fra erfaringerne med de lande, som 2004 tilsluttede sig unionen, vil de positive virkninger af tilpasningen til EU blive styrket efter optagelsen.

\section{Hvad tager de med sig}

Det er klart nok at se, hvilke problemer de to lande bringer ind i EU. Et af dem er forureningen fra minedriften i den centrale del af Rumænien, hvor bl.a. guldproduktionen ikke blot ødelægger det lokale miljø, men også indebærer en risiko, der via floderne rækker ud over landets grænser. 
Bulgariens kraftforsyning sker i betydeligt omfang ved atomkraft fra forældede værker, og et nyt er på bedding. Udviklingen er ujæunt fordelt inden for de to lande. De regionale forskelle er særlig store i Rumænien, ikke blot fordi landet er over dobbelt så stort som Bulgarien, men også fordi det historisk set har været delt mellem to meget forskellige imperier, det østrig-ungarske og det osmanniske. Områderne i sydvest, som har været en del af Ungarn, har haft en anden udvikling end Moldavien og Bukovina i nordøst.

Disse forskelle er ikke blevet udjævnet af snart 90 års fælles historie, lige så lidt som store forskelle mellem by og land. Og Nicolae Ceaucescus brutale moderniseringsforsøg især i 1980'erne var bestemt ikke vellykkede. Der er kort sagt god brug for regionale støttemidler i de to nye medlemslande.

Bulgarien og Rumænien bringer næsten 30 millioner mennesker med sig, hvoraf ca. 85 pct. er ortodokse kristne. Det medfører en væsentlig styrkelse af denne trosretning i EU, med fire lande så at sige på stribe: Cypern, Grækenland, Bulgarien og Rumænien. Bulgariens og Rumæniens optagelse skærper også behovet for en styrkelse af indsatsen over for roma-folket, som udgør en procentvis stor del af de to landes befolkning, hhv. 4,6 pct. (Bulgarien) og 2,5 pct. (Rumænien). Til sammenligning udgør de 1,7 pct. af befolkningen i Slovakiet og en halv pct. af befolkningen i Ungarn.

Samtidig medbringer de to lande på det østlige Balkan Europas nok rigeste skat af folkemusik og folkedans. Begge landene vil bidrage til en berigelse af den kulturelle mangfoldighed i Europa med mange enestående kulturminder. Desuden har de fremragende turistområder med fine badestrande langs Sortehavet, men klart med et behov for videreudvikling af infrastrukturen. Rumænien har specielt et stort potentiale i kurbade og andre helsetilbud.

De to lande har hidtil haft en negativ befolkningsudvikling, og især ungdommen har været interesseret i at udvandre. Bulgarien er særlig hårdt ramt med et fald i befolkningen årligt på 0,8 pct. mens det tilsvarende tal for Rumænien er 0,3 pct. (Til sammenligning ligger Rusland på $-0,5$ pct og Italien på $-0,1$ pct.) . Men sammenligner man med ældre EU-lande med udviklingsproblemer, skulle der være en mulighed for at vende den negative befolkningsudvikling, som nu er karakteristisk for begge landene.

Karsten Fledelius er lektor ved Institut for Film- og Medievidenskab, Københavns Universitet. 